\title{
Erisuuruisten ruokakuntien kulutustaso Engelin käyrien avulla mitattuna ${ }^{1}$
}

\author{
Valtiot. maist. KAI SARAMO \\ Talous- ja yhteiskuntatieteiden laitos \\ Ruotsalainen kauppakorkeakoulu
}

\section{Engelin laki}

Viime vuosisadalla elänyt preussilainen tilastomies Ernst Engel havaitsi perheruokakuntien menoja tutkiessaan tiettyä säännönmukaisuutta käytettävissä olevien tulojen ja niiden käyttötavan välillä. Huomionsa hän kiteytti seuraavaan toteamukseen, joka on tullut tunnetuksi Engelin lain nimellä:

Ruokakunnat joilla on samanlaiset kulutustavat ja jotka joutuvat maksamaan eri hyödykkeistä samat hinnat, käyttävät tulojen kasvaessa keskimäärin yhä pienemmän osan niistä ravintoon, tai yleisemmin:

Edellä mainitulla tavalla rajoitettu joukko ruokakuntia käyttää tulojen kasvaessa keskimäärin yhä pienemmän osan niistä välttämättömiin ja yhä suuremman osan suhteellisen ylellisyysluontoisiin hyödykkeisiin.

Tasossa, jonka X-akselina on käytettävissä olevat tulot ja Y-akselina välttämättömyysmenojen osuus, kuvaavat kulutuksen rakennetta luoteesta kaakkoon kulkevat käyrät. Mm. tämänlaatuisia käyriä sanotaan Engelin käyriksi, joista on esimerkkejä kuvioissa $3 \mathrm{a}$ ja $3 \mathrm{~b}$.

Engel esitti lakinsa niin varhain kuin vuonna 1857, mutta yleistä huomiota se herätti vasta uudelleen julkaistuna vuonna 1895. Se edustaa ekonometrisen työn ensimmäisiä merkittäviä saavutuksia. (Ks. esim. Schumpeter, s. 961.)

\section{Tehtävä}

Mikäli ruokakunnat, joiden tuloja ja menoja tutkitaan, ovat edellä esitetyllä tavalla yhdenlaatuisia, siis samanlaiset kulutustavat omaavia, voidaan tehdä johtopäätöksiä erisuuruisten ruokakuntien kulutustasosta

1 Tutkielman aiheen olen saanut professori Gunnar Fougstedtilta. 
Engelin käyriä hyväksi käyttäen. Kun eri ruokakuntatyyppien käyrät piirretään samaan tasoon, kuten kuviossa 3 on tehty, ilmaisevat niiden väliset vaakasuorat etäisyydet, miten paljon enemmän rahaa suurempi ruokakunta tarvitsee ollakseen samalla tarpeiden tyydytystasolla kuin pienempi.

Toisaalta on jo alusta pitäen selvää, kun tarkastetaan lukuisia ruokakuntia, etteivät ne voi olla kauttaaltaan yhdenlaatuisia. Jos yhdenlaatuisuuden puute on rippumaton tulomuuttujasta, siitä ei ole sanottavaa haittaa; se ilmenee silloin vain erisuuruisena satunnaisvaihteluna, ja sen vaikutusta voidaan periaatteessa vähentää miten paljon tahansa lisäämällä tutkittavaan näytteeseen sisältyvien ruokakuntien lukua. On kuitenkin syytä olettaa, että ihmisten kulutustavat ovat eri tuloasteilla erilaiset. Siinä määrin kuin tämä olettamus pitää paikkansa, hämärtyy edellä esitetyllä tavalla saatava kuva erisuuruisten ruokakuntien kulutustasosta tulojen vaihdellessa.

Tämän tutkielman tarkoituksena on 1) laskea ja kuvata eri ruokakuntatyyppien Engelin käyrät Suomessa viimeksi — vuosina 1955-1956 — toimeenpannun kulutustutkimuksen aineiston perusteella sekä 2) verrata laskettuja käyriä hypoteettisiin, ennakolta arvioituihin käyriin ja mikäli mahdollista saada ainakin osittainen selitys mahdollisesti todettaviin eroavuuksiin.

\section{Hypoteesi}

Erisuuruisten perheiden kulutustarpeita on vanhastaan verrattu toisiinsa ns. kulutusyksikköjärjestelmien avulla. Ne perustuvat eri sukupuolta olevien ja eri-ikäisten yksilöiden tarpeiden lääketieteellisiin (varsinkin ravinnon osalta) ja muilla keinoin suoritettuihin mittauksiin. Kulutustutkimusten tuloksia ei yleensä ole käytetty hyväksi kulutusyksikköjärjestelmiä laadittaessa, koska ne kuvastavat pikemminkin tulojen kuin tarpeiden vaihteluja. Tästä johtuen nämä järjestelmät ovat kulutustutkimuksista riippumattomia ja muodostavat täten erinomaisia hypoteettisia vertailukohteita kulutustutkimuksen aineistoon perustuvia laskelmia tarkasteltaessa.

Kulutusyksikköjärjestelmiä on olemassa lukuisia. Yleensä ne eroavat siksi vähän toisistaan, ettei yhtäkään voida asettaa ehdottomasti etusijalle. Tässä tullaan käyttämään seuraavia arvoja, jotka antavat naisten ja lasten kulutustarpeille jonkin verran pienemmän painon kuin nykyään on tavallista: ${ }^{1}$

1 Vrt. esim. Samhället ..., s. 159 eteenpäin, jossa Erland v. Hofsten päätyy arvoihin mies $=1.0$, nainen $=1.0$ ja lapsi keskimäärin $=0.6$. 
Asetelma 1

\begin{tabular}{llll} 
& & \multicolumn{2}{c}{$\begin{array}{c}\text { Kulutusyksikköjä } \\
\text { (koko kulutus) }\end{array}$} \\
Mies $\ldots \ldots \ldots \ldots \ldots \ldots \ldots \ldots$ & 1.0 & 0.55 \\
Nainen $\ldots \ldots \ldots \ldots \ldots \ldots \ldots$ & 0.8 & 0.45 \\
Lapsi keskimäärin $\ldots \ldots \ldots$ & 0.5 & 0.28 \\
Mies ja nainen $\ldots \ldots \ldots \ldots$ & 1.8 & 1.00
\end{tabular}

Kulutusyksikköluvuissa useimmiten ei oteta huomioon lasten hoitokustannuksia, mikä johtaa lapsiperheiden todellisten menojen aliarviointiin.

Hypoteesimme tulee olemaan, että vuosien 1955-1956 kulutustutkimuksen perusteella lasketut Engelin käyrät osoittavat asetelman 1 mukaisia keskimääräisiä tuloeroja niiden erisuuruisten ruokakuntien välillä, jotka käyttävät saman osuuden tuloistaan välttämättömiin hyödykkeisiin.

\section{Laskelmat}

Seuraavissa empiirisissä laskelmissa ravintomenot edustavat kaikkia välttämättömiä menoja. On sanomattakin ilmeistä, että on muitakin välttämättömiä menoja, eivätkä toisaalta kaikki ravintomenot ole välttämättömiä, mutta kulutuksen pääryhmistä viimeksimainitut edustavat parhaiten ensisijaisten tarpeiden tyydyttämiseen käytettyjä varoja.

Käytettävissä olevat tulot on tässä määritelty seuraavasti:

kokonaistulot

- verot

— säästöt

- velat

käytettävissä olevat tulot $=$ kokonaismenot

Ruokakuntakohtaiset tiedot ravintomenoista ja käytettävissä olevista tuloista saatiin sosiaalisesta tutkimustoimistosta. Yksinäisten miesten sekä lapsettomien, yhden lapsen, kahden lapsen ja kolmen lapsen perheiden lukumäärät ilmoitetaan asetelmassa 2 paikkakuntaryhmittäin. Kuviossa 1 esitetään käytettävissä olevat tulot ja ravintomenojen osuus ilman paikkakuntaryhmitystä. Kaikki muut ruokakuntatyypit paitsi yksinäiset naiset olivat niin heikosti edustettuina, että niistä ei ole voitu suorittaa laskelmia. Yksinäiset naiset on jätetty ulkopuolelle siitä syystä, että huomattava osa heidän reaalituloistaan saavutetaan kodin piirissä suoritettavalla ruoanlaitto-, ompelu- ym. työllä, mikä tekee heidän kulutuksensa kovin poikkeukselliseksi. Yksinäiset miehet kuluttavat toisaalta erityisen paljon kodin ulkopuolella. Heidät onkin otettu mukaan pääasiallisesti perheruokakuntien vertailukohteeksi. 
1. Yksinäiset miehet Lonely men

2. Puolisot ilman lapsia Families without children

3. Puolisot ja 1 lapsi Families with one child

4. Puolisot ja 2 lasta Families with two children

5. Puolisot ja 3 lasta

Families with three children

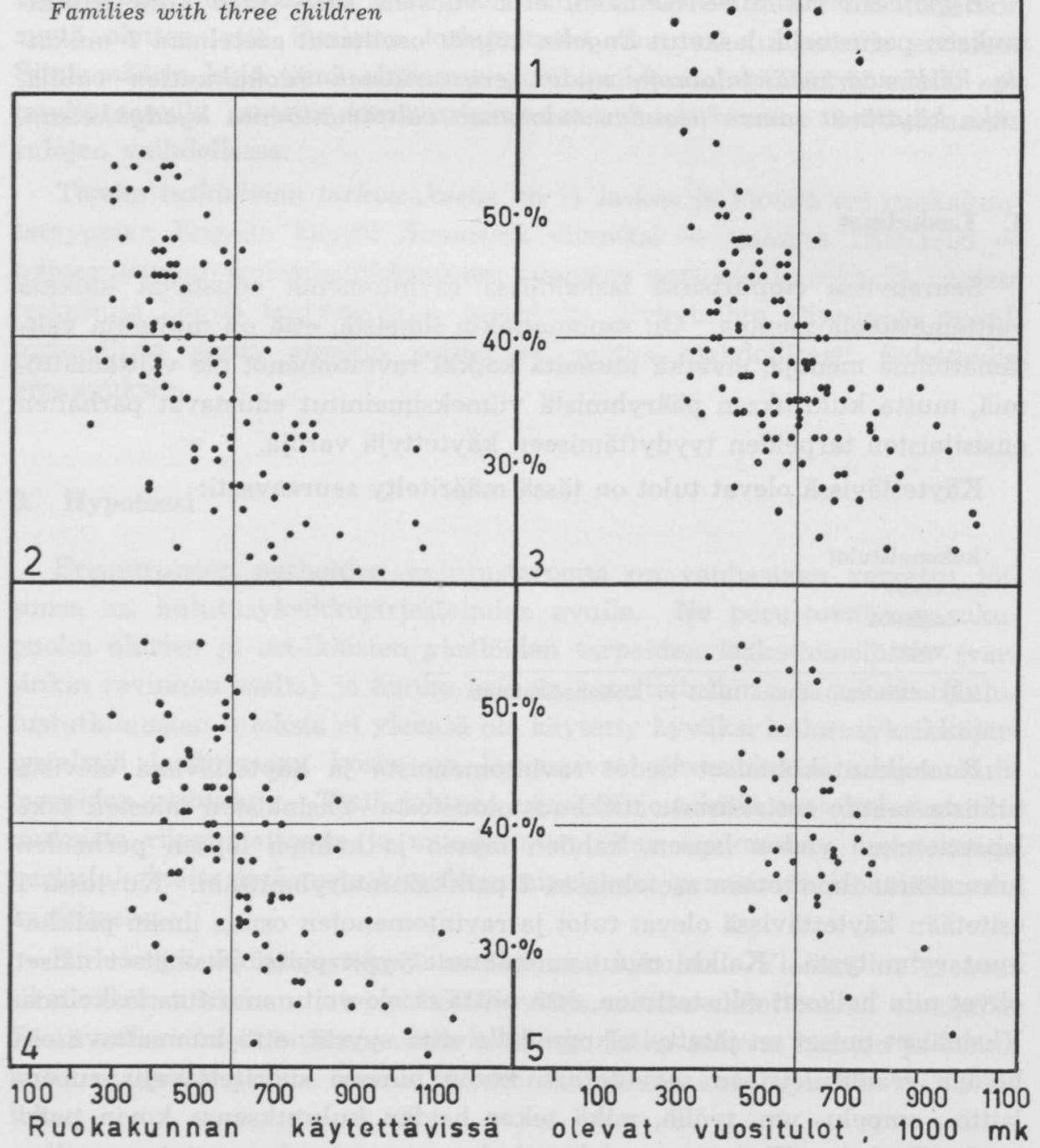

$\mathrm{Kuvio}$ 1. Erisuuruisten ruokakuntien ravintomenojen prosenttinen osuus käytettävissä olevista tuloista tulojen vaihdellessa.

Figure 1. Scatter diagrams of disposable income (X-axis) and food expenditure in per cent of disposable income. 


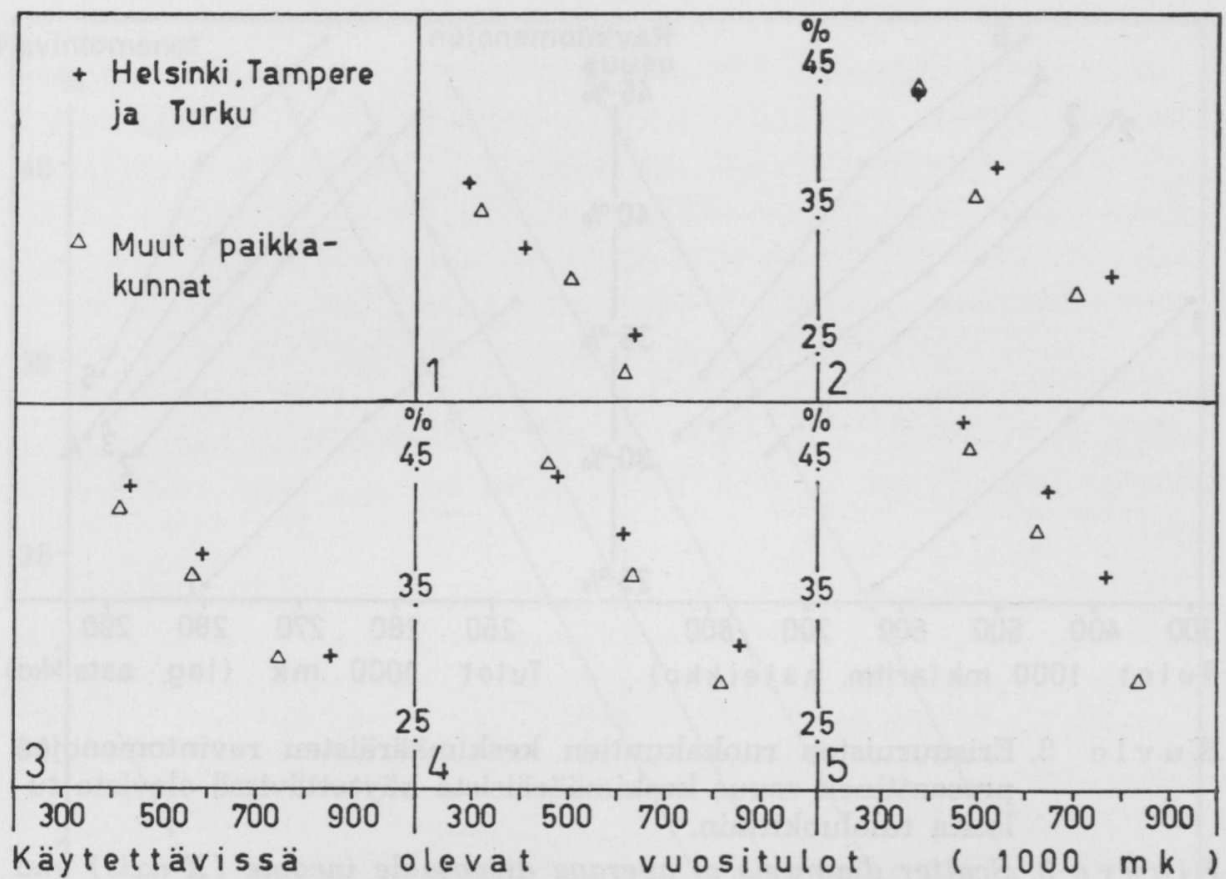

$\mathrm{Kuvio}$ 2. Erisuuruisten ruokakuntien keskimääräisten ravintomenojen prosenttinen osuus keskimääräisistä käytettävissä olevista tuloista tuloluokittain ja paikkakuntaryhmittäin.

Figure 2. Scatter diagrams of average disposable income (X-axis) and average food expenditure in per cent of disposable income by income classes and sizes of domicile.

Numerot $1-5$ viittaavat talouskuntatyyppeihin, jotka on selitetty kuviossa 1.

The numbers 1-5 refer to household types as explained in the legend of fig. $1 .-+=$ towns with over 100000 inhabitants, $\Delta=$ towns and market towns with less than 100000 inhabitants.

As a te $1 \mathrm{ma} 2$

Ruokakuntatyyppi

Yksinäiset miehet

Puolisot ilman lapsia $\ldots \ldots \ldots \ldots \ldots$

32

Puolisot ja 1 lapsi .............. 27

Puolisot ja 2 lasta .............. 22

Puolisot ja 3 lasta .............. 7

Kaikkiaan 97
Helsinki Tampere Keskija suuret Turku kaupungit

19

19

16

21

5

65

4
25
29
18
9
85

85
Pienet paikka- Yhteensä kunnat

$\begin{array}{rr}5 & 22 \\ 25 & 101 \\ 43 & 115 \\ 26 & 87 \\ 23 & 44 \\ 122 & 369\end{array}$

Kuviossa 1 esitettyä aineistoa tiivistettäessä on menetelty seuraavasti. Jokaisen ruokakuntatyypin ruokakunnat on jaettu käytettävissä olevien tulojensa mukaan kolmeen lukumäärältään lähipitäen yhtä suureen luokkaan, jolloin edellisessä asetelmassa mainitut neljä paikkakuntaryhmää on pidetty 


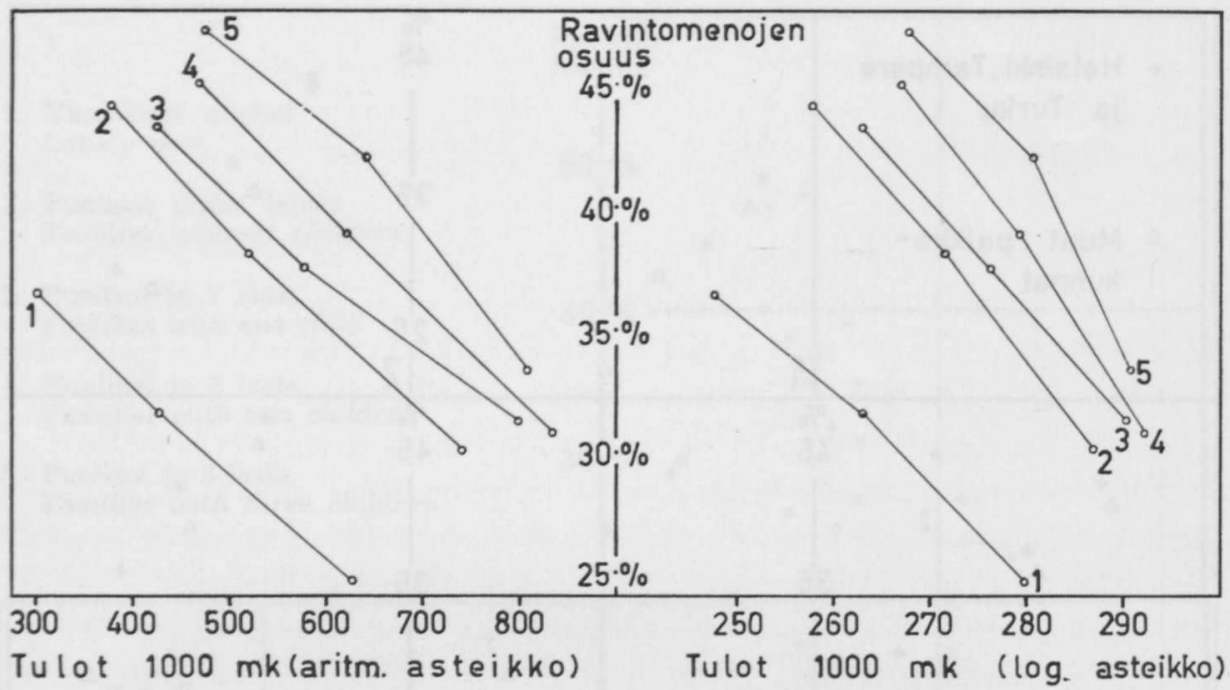

K uvio 3. Erisuuruisten ruokakuntien keskimääräisten ravintomenojen prosenttinen osuus keskimääräisistä käytettävissä olevista tuloista tuloluokittain.

Figure 3. Scatter diagrams of average disposable income (X-axis) and average food expenditure in per cent of disposable income by income classes.

Numerot $1-5$ viittaavat talouskuntatyyppeihin, jotka on selitetty kuviossa 1 .

The numbers 1-5 refer to household types as explained in the legend of fig. 1. - a. Arithmetic grid. b. Semi-logarithmic grid.

erillään. Näin saaduille 60 ruokakuntaryhmälle on laskettu keskimääräiset käytettävissä olevat tulot ja ravintomenojen keskimääräinen osuus. Tällöin huomattiin, että tämä osuus kasvaa melko säännöllisesti paikkakunnan väkiluvun lisääntyessä (ks. kuviota 2). Koska suurkaupungeista on saatu suhteellisesti vähemmän lapsiperheitä kuin pienemmiltä paikkakunnilta, on eri paikkakuntaryhmien tietoja yhdistettäessä kullekin ryhmälle annettu sama paino. Parhaaseen ratkaisuun, vain yhden paikkakunnan tietojen käyttämiseen, ei ole voitu mennä aineiston niukkuuden takia.

Mainitulla tavalla lasketut keskimääräiset suhdeluvut kaikilta paikkakunnilta esitetään kuvioissa 3 a ja 3 b. Kunkin ruokakuntatyypin kolme pistettä on yhdistetty suorilla, jolloin syntyy aineiston pienuuteen nähden yllättävän säännöllisiä katkoviivoja. Viivat ovat samansuuntaiset, kun tulot esitetään aritmeettisessa asteikossa, mikä merkitsisi sitä, että suurtuloiset alentaisivat tasoaan enemmän kuin pientuloiset mennessään naimisiin ja perheen kasvaessa. Olisi odottanut kun tulot esitetään aritmeettisessa asteikossa, että viivat erkanisivat toisistaan korkeampiin tuloihin 


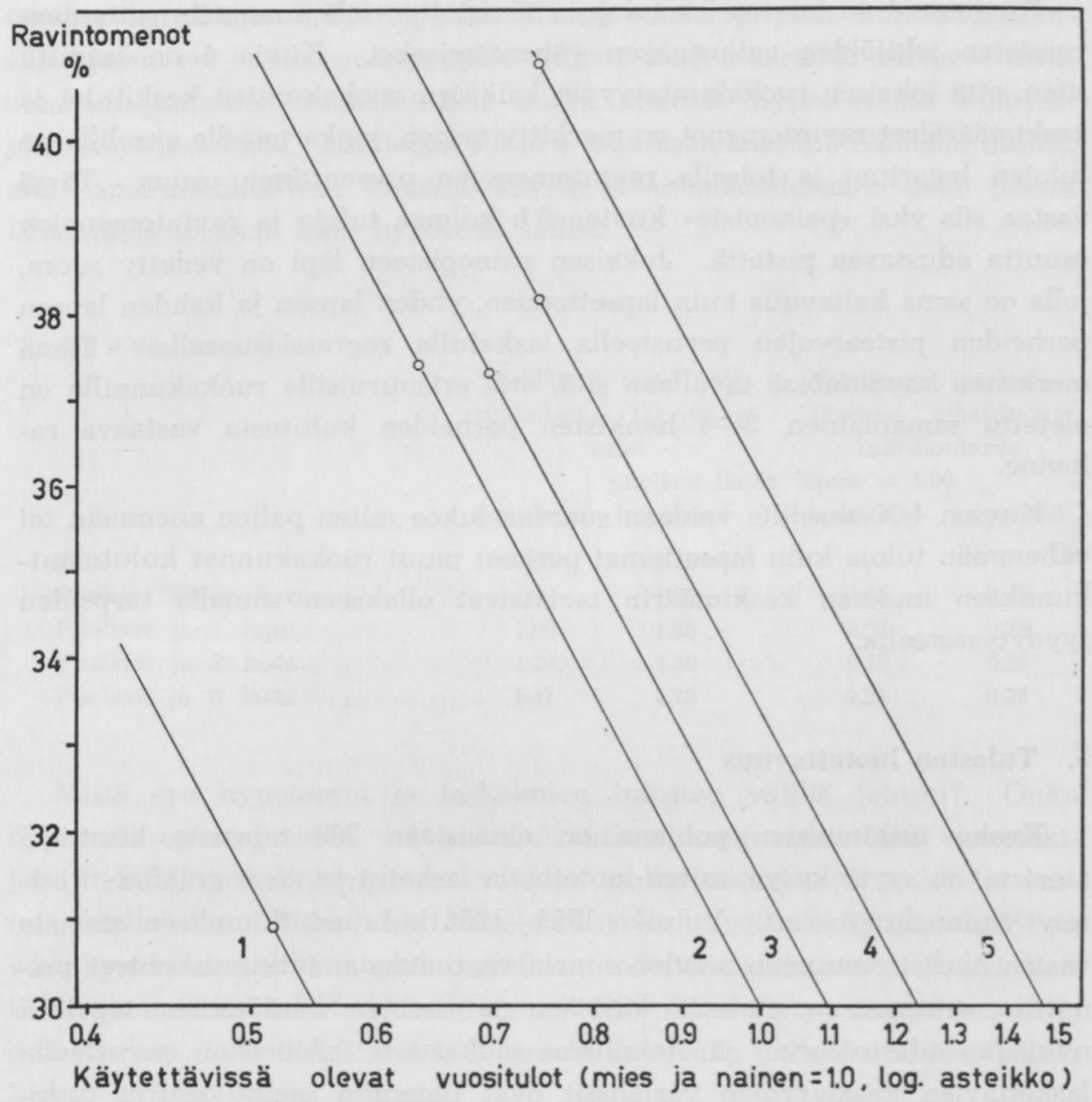

K uvio 4. Erisuuruisten ruokakuntien samansuuntaisiksi regressiosuoriksi tasoitetut Engelin käyrät.

Figure 4. Regression lines with the same slopes fitted to the curves of fig. $3 \mathrm{~b}$ with the average disposable income of families without children $=1.0$.

Numerot $1-5$ viittaavat talouskuntatyyppeihin, jotka on selitetty kuviossa 1.

Semi-logarithmic grid. The numbers 1-5 refer to household types as explained in the legend of fig. 1.

mentäessä, kun taas logaritmisessa asteikossa niiden olisi luullut olevan likipitäen samansuuntaiset. Tämä vastaisi sitä, että yhtä suuret suhteelliset tulonlisäykset toisivat yhtä suuren tarpeiden tyydytysasteen lisäyksen. Tämä teorian ja empiirisen aineiston eroavuus kuvastaa kulutustapojen tulojenmukaisia vaihteluita ja sitä yritetään selittää kohdassa 6 . 
Kuviossa 4 on kuvion $3 \mathrm{~b}$ tuloksia tiivistetty vielä enemmän sattumanvaraisten tekijöiden vaikutuksen vähentämiseksi. Kuvio 4 on laadittu siten, että jokaisen ruokakuntatyypin kaikkien ruokakuntien keskitulot ja keskimääräiset ravintomenot on merkitty tasoon, jonka toisella akselilla on tulojen logaritmi ja toisella ravintomenojen prosenttinen osuus. Tässä vastaa siis yksi "painopiste « kuvion 3 b kolmea tuloja ja ravintomenojen osuutta edustavaa pistettä. Jokaisen painopisteen läpi on vedetty suora, jolla on sama kaltevuus kuin lapsettomien, yhden lapsen ja kahden lapsen perheiden pistearvojen perusteella lasketulla regressiosuoralla. ${ }^{1}$ Tämä merkitsee käytännössä tavallaan sitä, että erisuuruisille ruokakunnille on oletettu samanlainen, $2-4$ henkisten perheiden kulutusta vastaava rakenne.

Kuvion $4 \mathrm{X}$-akselilta voidaan suoraan lukea miten paljon enemmän tai vähemmän tuloja kuin lapsettomat perheet muut ruokakunnat kulutustutkimuksen mukaan keskimäärin tarvitsivat ollakseen samalla tarpeiden tyydytysasteella.

\section{Tulosten luotettavuus}

Koska tutkimuksen pohjana on ainoastaan 369 tapausta käsittävä aineisto, on syytä kysyä, miten luotettavia lasketut ja tässä graafisesti esitetyt tunnusluvut ovat. Vuosien 1955-1956 kulutustutkimuksen aineisto vastaa harhattomuuteen nähden suuria vaatimuksia: tutkimuskohteet poimittiin satunnaismenetelmää käyttäen ja tietojen kerääminen tapahtui nykyajan tilastoteorian ja -tekniikan mukaisesti. Aineiston perusteella laskettavien keskiarvojen varianssit ovat tietenkin melko suuret tutkimuskohteiden pienestä lukumäärästä johtuen. Otantavariaatiolla ei kuitenkaan ole ratkaisevaa merkitystä tuloksia arvosteltaessa, koska tässä ei ole pyritty tarkkoihin arvioihin. Näin ollen voidaan tyytyä toteamukseen, että kuvioiden verrattain huomattava säännönmukaisuus tukee olettamusta, että sattumanvaraiset tekijät eivät ole päässeet pahemmin hämärtämään laskelmien avulla kulutuksesta saatavaa kuvaa.

\section{Laskelmatulosten analysointia}

Edellä arvioitiin etteivät sattumanvaraiset tekijät ratkaisevasti ole heikentäneet tulosten laatua. Sen sijaan tulokset vastaavat heikosti kohdan 3 lopussa esitettyä hypoteesia. On jo todettu, että perheen kasvaessa laskettu

1 Tällä tavalla laskettu regressiosuora on miltei sama kuin yksilöllisiin tietoihin perustuva. Ks. esim. Wold, s. 5 . 
tarvittavien tulojen lisäys oli suhteellisesti suurempi pien- kuin suurtuloisilla, joten eri ruokakuntatyyppien väliset keskimääräiset tuloerot eivät ainakaan kaikkien ruokakuntien osalta noudata hypoteettista kulutusyksikköjärjestelmää. Kuvioista 3 b ja 4 sekä asetelmasta 3 nähdään lisäksi, että lapsiruokakuntien Engelin käyrät kokonaisuudessaan ovat paljon lähempänä toisiaan kuin hypoteesi sallisi.

Asetelma 3

\begin{tabular}{|c|c|c|c|c|}
\hline & \multicolumn{2}{|c|}{$\begin{array}{c}\text { Yhtäläisen tason yllä- } \\
\text { pitämiseksi tarvittavat } \\
\text { tulot }\end{array}$} & \multicolumn{2}{|c|}{$\begin{array}{c}\text { Viimeisen perheen- } \\
\text { jäsenen aiheuttama } \\
\text { lisätulontarve }\end{array}$} \\
\hline & \multicolumn{4}{|c|}{ puolisot ilman lapsia $=1.00$} \\
\hline & laskelmat & hypoteesi & laskelmat & hypoteesi \\
\hline Mies & 0.55 & 0.55 & . & . \\
\hline Puolisot ilman lapsia & 1.00 & 1.00 & 0.45 & 0.45 \\
\hline Puolisot ja 1 lapsi & 1.09 & 1.25 & 0.09 & 0.28 \\
\hline Puolisot ja 2 lasta & 1.24 & 1.50 & 0.15 & 0.28 \\
\hline Puolisot ja 3 lasta & 1.47 & 1.75 & 0.23 & 0.28 \\
\hline
\end{tabular}

Mistä ero hypoteesin ja laskelmien tulosten välillä johtuu? Onko hypoteesi epärealistinen vai piileekö tutkimuksen aineistossa virhetekijöitä? Edelliseen kysymykseen voidaan melko suurella varmuudella vastata kielteisesti. Varovaisesti muotoillut kulutusyksikköjärjestelmät on vuosikymmenien aikana yhä uudelleen todettu paikkansa pitäviksi kaikesta summittaisuudestaan huolimatta. Erotuksen täytyy siis johtua siitä, että aineisto ei ole kohdissa 1 ja 2 mainitulla tavalla yhdenlaatuinen. Tähän löytyy todennäköinen selitys.

Ensinnä kulutustutkimuksissa ei ole katsottu mahdolliseksi ottaa huomioon kotitaloustyön arvoa, mikä tunnetusti usein on varsin huomattava. Tämä puute saattaa täysin selittää laskettujen ja hypoteettisten arvojen erotuksen, mikä kuviossa 4 tulee ilmi siten, että perheruokakuntien tasoitetut Engelin käyrät ovat liian lähellä toisiaan. Tätä olettamusta tukee se seikka, että yksinäisten miesten ja lapsettomien perheiden laskettujen ja hypoteettisten kulutustarpeiden suhteet ovat yhtä suuret. Näissä ruokakuntatyypeissä tulot kulutusyksikköä kohti ovat korkeat, minkä takia kotitaloustuotannon tarve jää pienemmäksi kuin lapsiperheissä, jonka lisäksi vaimon ansiotyö rajoittaa sitä. Asetelmassa 3 esitettyjen hypoteettisten ja empiiristen arvojen erot tarjoavat siis erään todellisuudessa suoritetun kotitaloustyön arvon mitan (ilman lastenhoitotyötä).

Toiseksi yhteisen kulutuksen merkitys lisääntyy tulojen kasvaessa. Kun huomattava osa käytettävissä olevista varoista kulutetaan auton, televisiovastaanottimen, kesämökin ja muiden verrattain ylellisyysluontoisten hyö- 
dykkeiden hankkimiseen, tapahtuu ilmeisesti perheenjäsentä kohti tarvittavassa tulossa suhteellista alenemista. Palvelevathan mainitut kestävät kulutushyödykkeet melkein yhtä hyvin ja suunnilleen samoin kustannuksin erisuuruisia perheitä. Yhteisen kulutuksen lisääntyminen tulojen noustessa selittänee huomattavalta osalta kuviossa $3 \mathrm{~b}$ esitettyjen Engelin käyrien erisuuntaisuuden. Sama vaikutus on myös sillä, että suuremmissa perheissä yleensä valmistetaan enemmän halpoja mutta paljon työtä vaativia ruokia; toisin sanoen osa ravintokustannuksista korvataan työkustannuksilla, ja koska nämä työkustannukset yleensä eivät sisälly kulutustutkimusten lukuihin, jäävät mitatut ravintokustannukset todellisia alemmiksi. Tosin ulkopuolisesta talousavusta maksetut korvaukset otetaan huomioon kulutustutkimuksissa, mutta ei edes osaa ravintomenojen kohdalla.

Lopuksi voidaan kuviosta 4 ja asetelmasta 3 lukea, että kustannukset lasta kohti lisääntyvät lapsiluvun kasvaessa. Osasyynä tähän lienee se, että lasten keski-ikä nousee lapsiluvun mukana. Vuosien 1955-1956 kulutustutkimuksessa lasten keski-ikä vaihteli 6.0 vuodesta yhden lapsen perheissä 7.0 vuoteen kolmen lapsen perheissä. Ero ei ole suuri, mutta sillä on kouluikäisten lasten kohdalla merkitystä.

\section{Loppusanat}

Tässä esitetyn tapaisilla keinoilla voidaan varmaan saada paljon tosiasioihin perustuvaa lisävalaistusta erisuuruisten perheiden kulutusoloihin. Jotta päästäisiin todella merkitseviin tuloksiin, on kuitenkin välttämätöntä, että vastaisissa kulutustutkimuksissa hankittaisiin nykyistä paljon enemmän tietoja kotitaloudessa tapahtuvasta tuotannosta. Nykyisin käytettävissä olevat luvut antavat liian edullisen kuvan lapsiperheiden asemasta.

\section{Kirjallisuus}

Kulutustutkimus 1955-1956. Kaupungit ja kauppalat. SVT. XXXII: 22. Helsinki 1959. (Monistettuine taululiitteineen.)

Samhället och barnfamiljerna. SOU 1955: 29. Stockholm 1955.

Schumpeter, Joseph A. History of Economic Analysis. New York 1954.

Wold, Herman. Demand Analysis. Stockholm 1952. 


\section{Summary:}

\section{The Comsumption Level of Finnish Households of Different Sizes as Estimated by Means of Engel Curves}

\section{By KAI SARAMO}

Institute of Economics and Social Sciences

The Swedish School of Economics, Helsinki

The point of departure of the investigation here described is Ernst Engel's well-known law, which states that for a set of households having basically the same consumption habits and facing the same prices the proportion of total expenditure spent on urgent needs is as a rule a decreasing function of income. Graphically, this relation is represented by curves running from the upper left to the lower right in a plane with income along the horizontal, and the proportion spent on urgent needs along the vertical, axis. Figures $3 \mathrm{a}$ and $3 \mathrm{~b}$ show examples of these so-called Engel curves for households of different sizes. For apparent reasons the curves shift to the right when the average size of household increases.

It can be argued that under certain conditions not to be specified here households of different sizes will be on the same consumption level when spending the same proportions of their incomes on necessities. Assuming that the unspecified conditions are fulfilled empirical income distributions by sizes of household can be calculated from the corresponding Engel curves. When the unspecified conditions and those mentioned in Engel's law are moderated interesting conclusions are arrived at when comparing the empirical distribution to a hypothetical one or to a set of distributions.

The hypothesis used in the investigation was that households of different sizes will be on the same consumption level when their disposable incomes correspond to the following rather conservative consumer-unit scale, which refers to total consumption:

$\begin{array}{llll}\text { Man } \ldots \ldots \ldots \ldots \ldots \ldots \ldots & 1.0 & 0.55 \\ \text { Woman } \ldots \ldots \ldots \ldots \ldots & 0.8 & 0.45 \\ \text { Child on the average } \ldots \ldots & 0.5 & 0.28 \\ \text { Man and woman } \ldots \ldots \ldots & 1.8 & 1.00\end{array}$

Correspondingly, the empirical distribution was calculated from the appropriate Engel curves on the basis of the data established by the latest Finnish consumption investigation, undertaken in 1955-1956. Only part of its material is used here; it consists of 22 lonely men, 101 families without children, 115 with one child, 87 with two and 44 families with three children. Other household types are excluded as being too few or heterogenous. The computations are illustrated by figures $1-4$.

Fig. 1 shows the raw data, fig. 2 the same material divided into three income classes with the three largest towns forming a subgroup of their own. The Engel curves in fig. $3 \mathrm{a}$ and $3 \mathrm{~b}$ are standardized for size of domicile. Had the number of households been large enough it would of course have been better to use data for one town only instead of national averages with much wider dispersion.

As appears from fig. $3 \mathrm{a}$ and $3 \mathrm{~b}$ what has been assumed regarding the presence of homogenous consumption habits among households with different incomes is not borne out by facts. The Engel curves of fig. $3 \mathrm{~b}$, where the income scale is logarithmic, are converging instead of parallel. In other words, the relative increase in disposable income accompanying a rise in the number of consumer units decreases with disposable income, i.e. »wealthy» families lower their standard more than »poor» families. 
In fig. 4 straight lines are fitted to the Engel curves of fig. $3 \mathrm{~b}$. Their slope is the same as the average slope of the Engel curves for families with $0-2$ children. This means that all households are assumed to have the consumption habits of families with $0-2$ children.

When the disposable income of families without children is put $=1.00$, the empirical and hypothetical consumer unit scales are as follows:

\begin{tabular}{|c|c|c|}
\hline & Empirical & Hypothetical \\
\hline Man & 0.55 & 0.55 \\
\hline Woman & 0.45 & 0.45 \\
\hline First child & 0.09 & 0.28 \\
\hline Second , & 0.15 & 0.28 \\
\hline Third & $\ldots \quad 0.23$ & 0.28 \\
\hline
\end{tabular}

What is the reason of the marked discrepancy between the calculated and the theoretical expenditure of families with children? The conservative hypothetical consumer-unit scale cannot be so much off the mark, at least not in this direction. It seems more reasonable to conclude that the difference shows the value of work done at home, most of which does not appear from the account sheets of consumption investigations. As a matter of fact the established discrepancies provide a tentative measure of the value of unpaid domestic work.

The average cost of children seems to increase with their number. This is at least partly due to the fact that the average age of the children increases, too, from 6.0 years in families with one child to 7.0 years in families with three children. 